\title{
NEVADA BIRD RECORDS COMMITTEE REPORT FOR 2018
}

\author{
JEANNE TINSMAN, P. O. Box 752045, Las Vegas, Nevada 89136; \\ philohela17@gmail.com \\ MARTIN MEYERS, c/o Great Basin Bird Observatory, 1755 E. Plumb Lane \#256, \\ Reno, Nevada 89502; NevadaBirdRecords@gbbo.org
}

ABSTRACT: In 2018, the Nevada Bird Records Committee reviewed 56 reports from the period 23 May 1981-23 July 2018; 46 were endorsed. No new species were added to the state list, which stands at 489 species. The review list underwent a major revision in August 2018, reducing the number of full species requiring review from 141 to 108; two additional subspecies remain on the list.

The Nevada Bird Records Committee (NBRC) began 2018 with 19 reports pending review. During the year, 63 reports were added to the pending queue. Eight of those were either rescinded before review or combined with another record as representing a "continuing" individual. The committee completed reviews of 56 reports during 2018. Therefore, the year ended with 18 reports in the pending queue. Since its founding in 1994, the NBRC has reviewed 1401 reports, endorsing 1260 (89.9\%) of them.

At its founding in 1994, the committee decided not to review any sightings prior to that year, but it reversed that decision several years later. Fortunately, founding secretary James Cressman and his wife, Marian, continued to accumulate documentation for "pre-committee" reports. One of the committee's long-term goals since 2007 has been to organize and review as many of those reports as possible. In addition, the NBRC has also searched for additional reviewable documentation from multiple sources (e.g., museum specimens and journal articles) for early unreviewed reports. Since 2007, the committee has reviewed 211 reports of sightings prior to the committee's founding date; 178 of those have been endorsed. Of the 56 reports reviewed in 2018, 15 preceded the founding date, and 11 of them were endorsed. Six of those became the earliest NBRC-endorsed records.

Of the 56 reports reviewed by the committee in 2018, 46 were endorsed. Fourteen of the endorsed records were supported only by written documentation. Photographs accompanied the documentation for 32 of the endorsed records. Of those 32, one was also accompanied by a video recording, another by an audio recording. None were accompanied by video or audio without also being supported by photographs. For the first time since 2012, none of the records were supported by museum specimens. Of the 10 reports not endorsed, five included photographs. The remaining five were supported by written descriptions only.

The NBRC has six voting members, one of whom serves as chair, and a nonvoting secretary. During 2018, the committee's voting members were Aaron Ambos, Paul Hurtado, Greg Scyphers, Justin Streit, Jeanne Tinsman, and Ben Zyla. The position of secretary continued to be held by Martin Meyers, and the position of chairperson continued to be held by Jeanne Tinsman. At the end of 2018, Greg Scyphers and Aaron Ambos rotated off the com- 
mittee because of term limits; Frank Fogarty and Alex Harper were elected to assume those positions in 2019.

The NBRC's website at http:/gbbo.org/nbrc contains a statement of purpose, answers to frequently asked questions, links to a submission form that can be downloaded or completed online, the Nevada checklist, the review list, a list of current and past NBRC members, and the committee's bylaws. There is a link to a list of all submissions to the NBRC, with the status of each with respect to endorsement and, if available, a photograph. All previous NBRC reports are available through the website. NBRC reports through 2007 (1994-1996, 1997, 1998, 1999, 2000, 2004, 2005, and 2007) appeared in Great Basin Birds, published by the Great Basin Bird Observatory. Reports for 2008 through 2010 are available only at the NBRC website. Beginning with the 2011 report, annual reports have appeared in Western Birds.

\section{REVISIONS TO THE NEVADA STATE LIST}

There were no changes to the Nevada state list in 2018. At the end of the year, the list included 489 species, including the Arctic Warbler (Phylloscopus borealis) sensu lato, based on a bird identified only to the group comprising the Arctic, Kamchatka Leaf (P. examinandus), and Japanese Leaf (P. xanthodryas) Warblers (see Tinsman and Meyers 2018).

\section{REVISIONS TO THE NEVADA REVIEW LIST}

The Nevada review list underwent a major revision in August 2018. The NBRC members decided that our focus is to be the truly rare species observed in the state. The decision removed seven regionally exempt species (known to breed in restricted areas of Nevada) and any species of which the committee had endorsed at least five records in the preceding 15 years.

On further reflection, we found that all but one of the 27 species removed as a result of the latter criterion had at least five endorsed records in the preceding 10 years. The committee agreed then to amend the criterion to fit that circumstance; the 26 species that fell into that category are no more than uncommon visitors to Nevada. The Western Gull (Larus occidentalis), with only two endorsed records in the preceding 10 years, was reinstated to the review list. From this point forward, any species with five or more endorsed records within the most recent 10-year period is automatically removed from the review list.

While it is certainly still worthwhile to watch for trends in all of these species, the committee concluded that such trends could be monitored through www.eBird.org. This platform may not be quite as rigorous as the NBRC's review process, but it serves to illustrate trends.

Consequently, at the end of 2018, the NBRC had reduced its review list to 108 species. Two subspecies also remained on the list, the Mexican Mallard (Anas platyrhynchos diazi) and Eurasian Green-winged Teal (Anas crecca crecca). The committee placed the Mexican Mallard on the review list to accumulate data on its occurrence. There are five unreviewed reports of this subspecies, but we have decided to wait to review them until there is more clarity on its taxonomic status and identification criteria. The committee has endorsed four records of the Eurasian Green-winged Teal. 


\section{SPECIES ACCOUNTS}

Each species account is introduced with a header in the following format: English name; scientific name; and, in parentheses, the total number of endorsed records of the species (including those endorsed in this report), followed by the number of records endorsed in this year's report. An asterisk preceding the species' name signifies that the species is no longer on the review list. Two asterisks after the total of records denote that the number of records refers to a restricted review period, usually signifying that the species is no longer on the review list, was added to the review list because of a perceived drop in frequency of occurrence in Nevada, or was exempt from review in some locations.

After the heading for each species, each report of that species reviewed in 2018 is provided in the following format: NBRC report number, location (county in parentheses), and date or range of dates of observations submitted to the NBRC. If the report involved multiple birds, the number follows the date information. Then, for endorsed records, the name of each submitter, followed by the notation "(P)," "(V)," and/or "(A)" if he or she provided a photo, video, and/or audio recording, respectively; if there is no such annotation, only written documentation was provided. If the finder(s) sent documentation to the NBRC, their names are listed first. A semicolon follows the finders' names if other observers submitted additional documentation.

Multiple observations of a species are ordered chronologically. Any discussion of the species in general, not specific to an observation, concludes the account if warranted. In text, citations of the journals American Birds and National Audubon Society Field Notes are abbreviated AB and NASFN.

*BRANT Branta bernicla $\left(9^{* *}, 1\right)$. 2017-077, Henderson Bird Viewing Preserve (Clark), 6 Nov 2017. A. Harper (P). Immature, subspecies nigricans.

${ }^{*}$ TRUMPETER SWAN Cygnus buccinator $\left(5^{\star *}, 1\right)$. 2017-081, Bowman Reservoir (Clark), 29 Nov 2017, seven birds. A. Harper (P). All adults.

2018-001, Vya (Washoe), 30 Dec 2017, two birds. NOT ENDORSED. This is the only record in this year's report that failed to win endorsement because of a question over the birds' origin. The two immature birds wore collars identifying them as having been hatched in a captive-breeding program at the Topeka (Kansas) Zoo and then transported to Oregon, where they were released by Oregon Department of Fish and Wildlife (Chris Nicolai, U. S. Fish and Wildlife Service, in litt., 2017). They were last seen in Oregon on $3 \mathrm{Dec} 2017$. The majority of the committee did not think that the birds met the criteria for endorsement as naturally occurring individuals.

${ }^{*}$ BLACK SCOTER Melanitta americana $\left(14^{* *}, 1\right) .2018-027$, Sunset Park, Las Vegas (Clark), 16 Apr 2015. D. Chang, J. Roombos (P). Immature male.

COMMON GROUND-DOVE Columbina passerina (8, 1). 2018-035, Pahranagat National Wildlife Refuge (NWR) (Lincoln), 24 May 2018. NOT ENDORSED.

2018-043, Las Vegas Bay, Lake Mead National Recreation Area (NRA) (Clark), 23 Jul 2018. B. Zyla.

RUFF Calidris pugnax (6, 1). 2018-009, S-Line Reservoir, Fallon (Churchill), 29-30 Jan 2018. M. Meyers (P), N. Hoffman (P), R. Strickland, F. Welden (P; Figure 1), G. Scyphers (P), M. Andrews, D. Ghiglieri (V). First reported by Rob Lowry on 28 Jan 2015. This is the first winter observation of the Ruff in Nevada. Previous records are from April and September. 


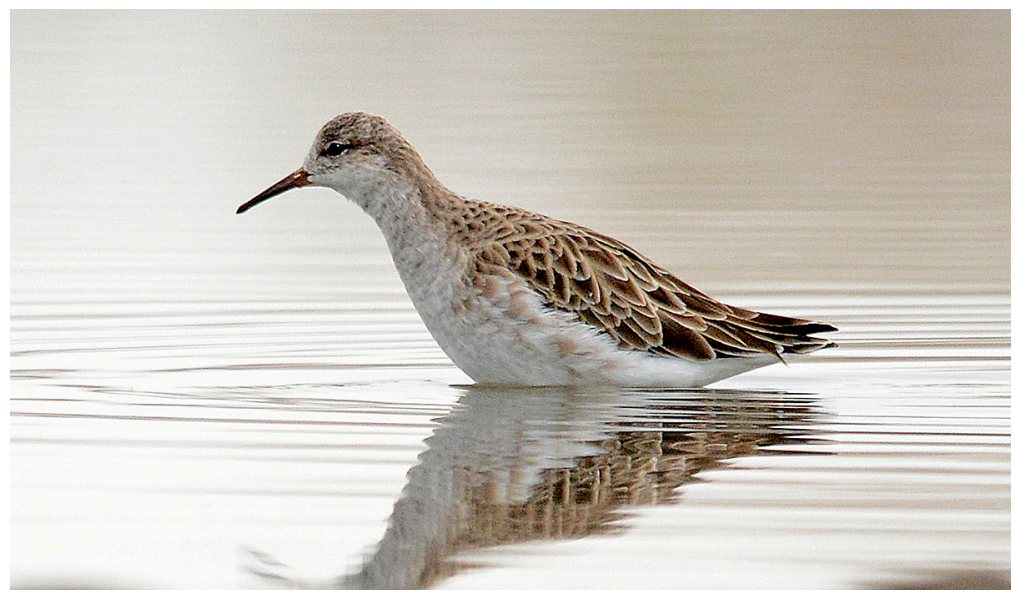

Figure 1. Ruff (Calidris pugnax), 29 Jan 2018, S-Line Reservoir, Fallon, Churchill County, Nevada.

Photo by F. Welden

LAUGHING GULL Leucophaeus atricilla $(4,1)$. 2018-020, Henderson Bird Viewing Preserve (Clark), 31 May 1992. M. Cressman, E. Wells (AB 46:455, 1992). Earliest NBRC-endorsed record. Immature.

*YELLOW-BILLED LOON Gavia adamsii $\left(10^{\star *}, 1\right) .2017-083$, Government Wash, Lake Mead NRA (Clark), 28 Dec 2017-21 Jan 2018. J. Streit (P); C. Wilhite (P), B. Zyla (P), J. Switalla (P; Figure 2). Immature.

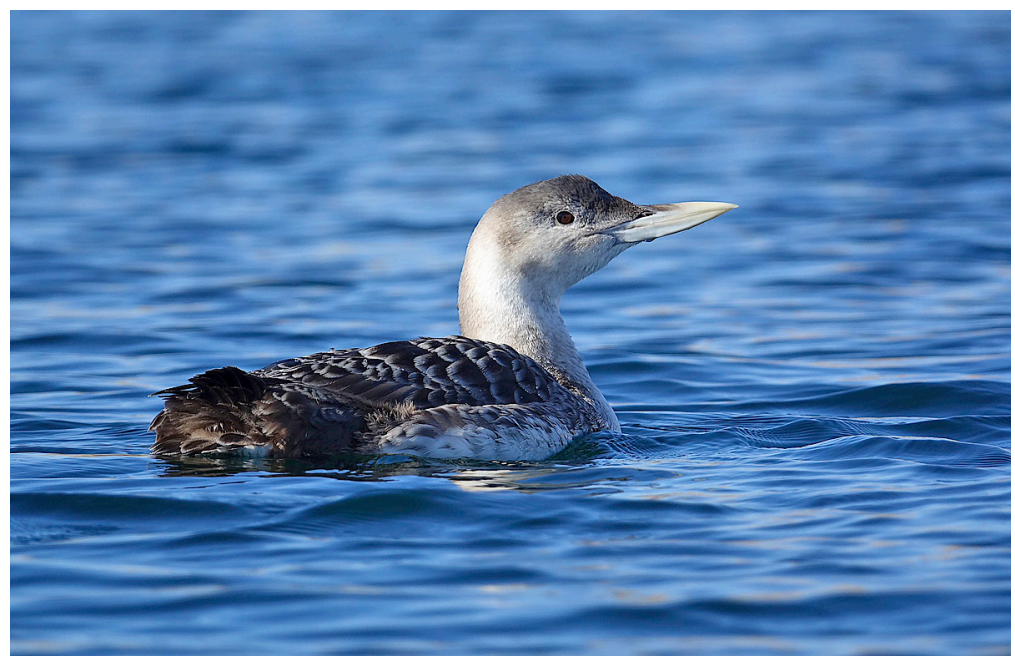

Figure 2. Yellow-billed Loon (Gavia adamsii), 15 Jan 2018, Government Wash, Lake Mead National Recreation Area, Clark County, Nevada.

Photo by J. Switalla 


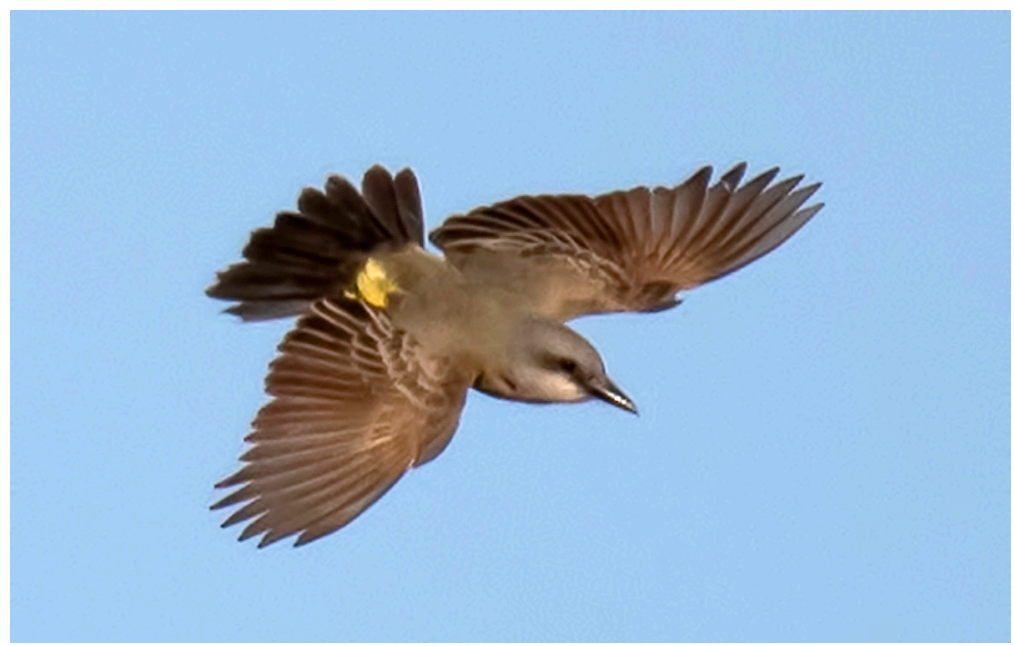

Figure 3. Tropical Kingbird (Tyrannus melancholicus), 8 Jun 2018, Corn Creek, Desert National Wildlife Refuge, Clark County, Nevada.

Photo by S. Krammer

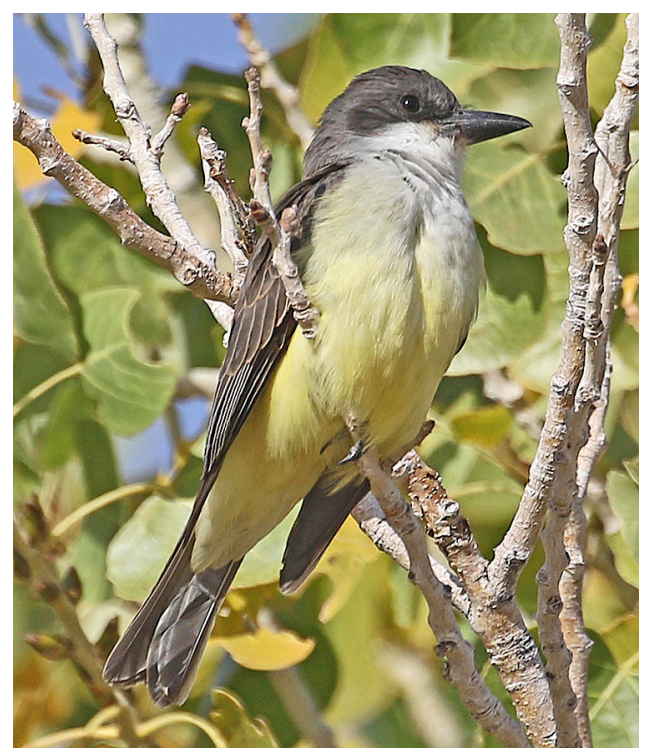

Figure 4. Thick-billed Kingbird (Tyrannus crassirostris), 13 Nov 2017, Floyd Lamb Park at Tule Springs, Las Vegas, Clark County, Nevada. 
REDDISH EGRET Egretta rufescens (4, 1). 2018-024, Lake Mead Marina (old location at Boulder Harbor), Lake Mead NRA (Clark), 23 Aug 1990. M. V. Mowbray, J. Harman (AB 45:132, 1991). Earliest NBRC-endorsed record. Adult.

${ }^{\star}$ MISSISSIPPI KITE Ictinia mississippiensis (11**, 3). 2018-021, Pahranagat Valley (Lincoln), 21 Mar 1982. NOT ENDORSED.

2018-014, Corn Creek, Desert NWR (Clark), 6 Jun 1986. M. V. Mowbray (AB 40:1234, 1986). Earliest NBRC-endorsed record. A second-year bird.

2018-022, Corn Creek, Desert NWR (Clark), 16 May 1992. R. Rucker, R. McArthur (AB 46:454, 1992). Adult.

2018-013, Corn Creek, Desert NWR (Clark), 14 May 1993. D. Crowe. Adult.

${ }^{\star}$ HARRIS'S HAWK Parabuteo unicinctus (13**, 1). 2017-082, Searchlight (Clark), 30 Nov 2017. J. Bundorf (P). Adult.

CRESTED CARACARA Caracara cheriway $(4,1)$. 2018-029, Amargosa Valley (Nye), 29 Apr 2018. L. Harter (P). Adult.

${ }^{*}$ LEAST FLYCATCHER Empidonax minimus (12**, 1). 2018-012, Blue Diamond (Clark), 24 Apr 1993. NOT ENDORSED.

2018-042R, Rafter 7 Ranch (Lyon), 11 Jun-2 Jul 2018. M. Dorriesfield (P, V, A). Found singing on the same study plot on a private ranch where Dorriesfield had documented a singing Least Flycatcher on 9 Jun 2016, endorsed as record 2016-033 (Tinsman and Meyers 2018). He did not survey the plot in 2017. The committee, on a 4-2 vote, decided to consider 2018-042 to be a return of 2016-033.

DUSKY-CAPPED FLYCATCHER Myiarchus tuberculifer (2, 1). 2018-028, Warm Springs Natural Area (Clark), 15 Apr 2018. B. Wilcox (P, A). Adult. Nevada's only previous Dusky-capped Flycatcher occurred in mid-December 2012 (Meyers 2015).

TROPICAL KINGBIRD Tyrannus melancholicus $(2,1)$. 2018-039, Corn Creek, Desert NWR (Clark), 8-9 Jun 2018. J. Streit (P); S. Krammer (P; Figure 3), J. Tinsman (P), N. McDonal (P). Adult female; flight shots provided the opportunity to verify that the outer primaries were notched, but not to the degree that would be observed on an adult male. Streit heard the characteristic twitter call that distinguishes the Tropical Kingbird from the similar Couch's Kingbird (T. couchii).

THICK-BILLED KINGBIRD Tyrannus crassirostris (4, 1). 2017-073, Floyd Lamb Park (Clark), 13 Nov-1 Dec 2017. J. Tinsman (P), C. Gaffey (P; Figure 4), P. Gaffey (P), N. McDonal (P), C. Coxe (P), B. Zyla (P). Found by Rita Schlageter. A hatch-year bird. Previous Nevada records come from late October to early November in 1996, 2014, and 2017. This species is observed nearly annually in California, thanks to wintering birds returning year after year (Tietz and McCaskie 2019). The first and only record in Utah was from 2009 (UBRC 2019).

*SCISSOR-TAILED FLYCATCHER Tyrannus forficatus (15**, 3). 2018-030, Warm Springs Natural Area (Clark), 10-13 May 2018. E. Swanson (P); M. Dorriesfield (P). Adult.

2018-033, Corn Creek, Desert NWR (Clark), 19 May 2018. C. Ritter (P). Adult. 2018-038, Corn Creek, Desert NWR (Clark), 7 Jun 2018. Desert NWR Corn Creek staff $(\mathrm{P})$. Adult. The committee considered whether it would be appropriate to combine 2018-033 and 2018-038 into a single record; photos were not definitive in clarifying whether they represented the same individual. Because Corn Creek (an oasis surrounded by desert) is one of the most heavily birded locations in southern Nevada and the species is hard to miss, the majority agreed that it was unlikely that the bird remained during the period between the two sightings without being reported. 
${ }^{\star}$ WHITE-EYED VIREO Vireo griseus $\left(10^{\star *}, 2\right) .2018-045$, Corn Creek, Desert NWR (Clark), 17 Jun 2018. B. Zyla. Adult.

2018-041, Floyd Lamb Park (Clark), 7 Jul 2018. B. Miller (P). Adult.

${ }^{\star}$ PURPLE MARTIN Progne subis $\left(17^{\star *}, 1\right)$. 2018-040, Corn Creek, Desert NWR (Clark), 11 Jun 2018. B. Miller (P); B. Zyla.

WINTER WREN Troglodytes hiemalis (3, 0). 2017-079, Floyd Lamb Park (Clark), 21 Nov 2017. NOT ENDORSED. This bird was heard once giving what the observer described as a rapid alarm call at a distance of about 150-200 feet. It was not heard again. Photos showed plumage that suggested the Winter Wren, but the committee decided that they did not conclusively eliminate the more likely Pacific Wren (T. pacificus).

RUFOUS-BACKED ROBIN Turdus rufopalliatus (2, 1). 2017-076, Spring Mountain Ranch State Park (SP) (Clark), 25 Nov-3 Dec 2017. J. Thompson (P); A. Poe (P), D. Crail-Rugotzke, J. Streit (P), B. Zyla, M. Meyers (P; Figure 5). A hatch-year bird. Another was observed at the same time $195 \mathrm{~km}$ to the southwest in California at Barstow Community College (Singer et al. 2020). The only other Rufous-backed Robin confirmed in Nevada occurred on 14 and 15 Nov 2012 (Meyers 2015).

${ }^{\star}$ PURPLE FINCH Haemorhous purpureus (20**, 10). 2018-015, Corn Creek, Desert NWR (Clark), 13 Mar 1993. NOT ENDORSED.

2018-004, Carson River Park, Carson City (Carson City), 24 Nov 2016, three birds. NOT ENDORSED.

2017-074, Corn Creek, Desert NWR (Clark), 5-18 Nov 2017. A. Harper (P), B. Miller (P); C. Gaffey (P), P. Gaffey, J. Tinsman (P).

2017-080, Red Rock Canyon National Conservation Area (Clark), 5 Nov 2017-4

Jan 2018, three birds. C. Neumamn (P), J. Streit (P).

2018-010, Floyd Lamb Park (Clark), 18 Nov 2017. NOT ENDORSED.

2017-075, Rancho San Rafael Park, Reno (Washoe), 21 Nov-24 Dec 2017, three birds. P. Hurtado (P, A); J. Bleam (P), M. Meyers (P), F. Petersen (P). (P).

2018-005, Riverview Park, Carson City (Carson City), 8-17 Dec 2017. N. Rosen

2018-007, Verdi (Washoe), 10 Jan 2018. P. Hurtado (P).

2018-003, Caughlin Parkway, Reno (Washoe), 10-18 Jan 2018, three birds. P. Hurtado (P); M. Meyers (P), J. Bleam (P).

2018-006, Upper Plateau Road, Reno (Washoe), 20-23 Jan 2018, four birds. M. Meyers (P).

2018-008, Reno (Washoe), 23-26 Jan 2018, seven birds. L. Dimitroff (P).

2018-017, Chrissie Caughlin Park, Reno (Washoe), 4 Feb 2018. P. Hurtado (P). 2018-031, Primm (Clark), 11 Apr 2018. B. Zyla (P).

The NBRC report for 2017 (Tinsman and Meyers 2019) described the increasing frequency of satisfactorily documented reports of the Purple Finch beginning around 2014. It is clear that the increase continued through 2018. NBRC members did not always indicate the subspecies when voting on these records, but none were thought to represent $H$. p. purpureus.

${ }^{\star}$ LAWRENCE'S GOLDFINCH Spinus lawrencei $\left(18^{\star *}, 1\right) .2018-011$, Red Rock Canyon National Conservation Area (Clark), 24 Apr 1994. M. Cressman (NASFN $48: 324,1994)$. Adult male. This species was removed from the Nevada review list in 2011; this early record antedates that decision.

SMITH'S LONGSPUR Calcarius pictus $(3,1)$. 2018-026, Henderson Bird Viewing Preserve (Clark), 30 Mar 1991. M. Cressman. Adult male. A detailed written description of the bird, which was in breeding plumage, resulted in a unanimous vote for endorsement. Though Smith's Longspurs are often gregarious, Cressman stated, "it did not pay attention to us or other birds except to avoid a Savannah Sparrow now and then." 


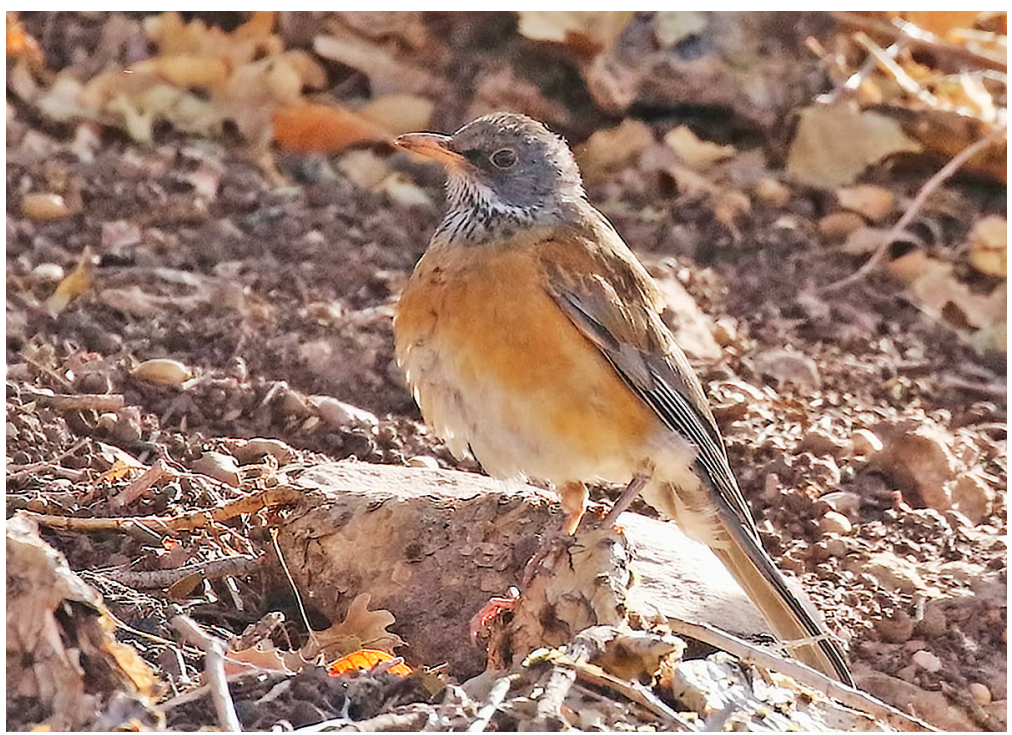

Figure 5. Rufous-backed Robin (Turdus rufopalliatus), 3 Dec 2017, Spring Mountain Ranch State Park, Clark County, Nevada.

Photo by M. Meyers

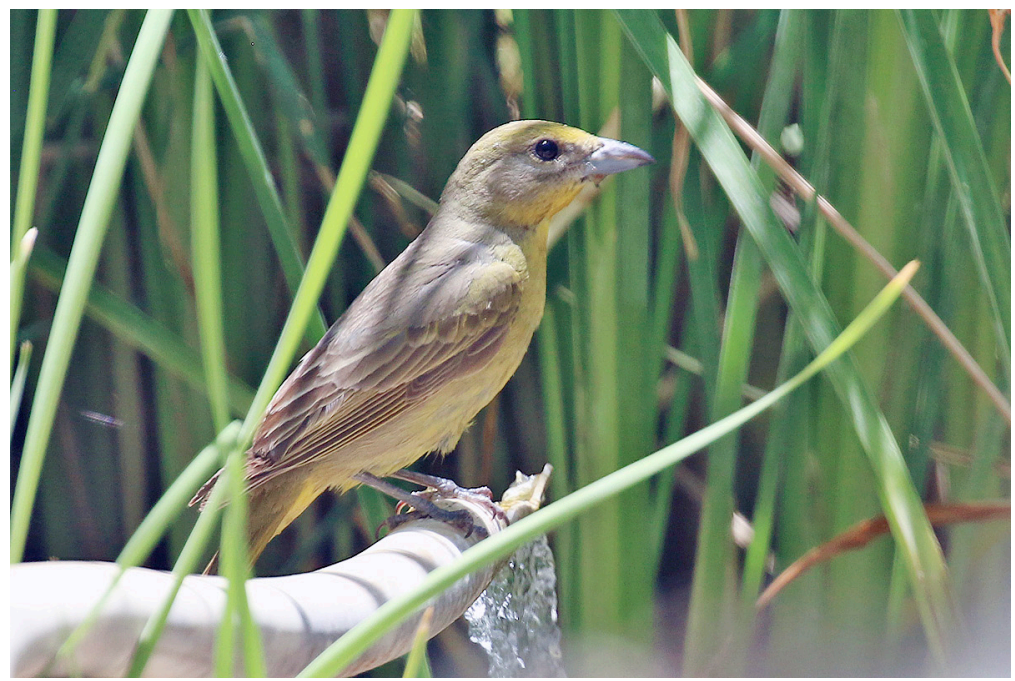

Figure 6. Hepatic Tanager (Piranga flava), 4 Jun 2018, Cactus Springs, Clark County, Nevada.

Photo by G. Scyphers 


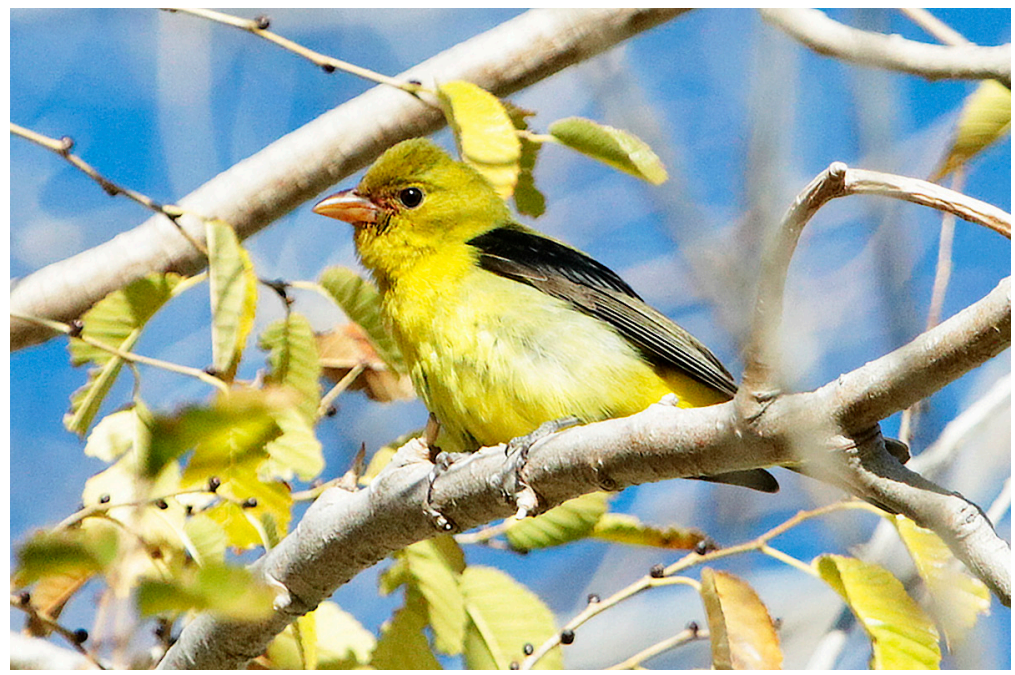

Figure 7. Scarlet Tanager (Piranga olivacea), 4 Nov 2017, Corn Creek, Desert National Wildlife Refuge, Clark County, Nevada.

Photo by N. McDonal

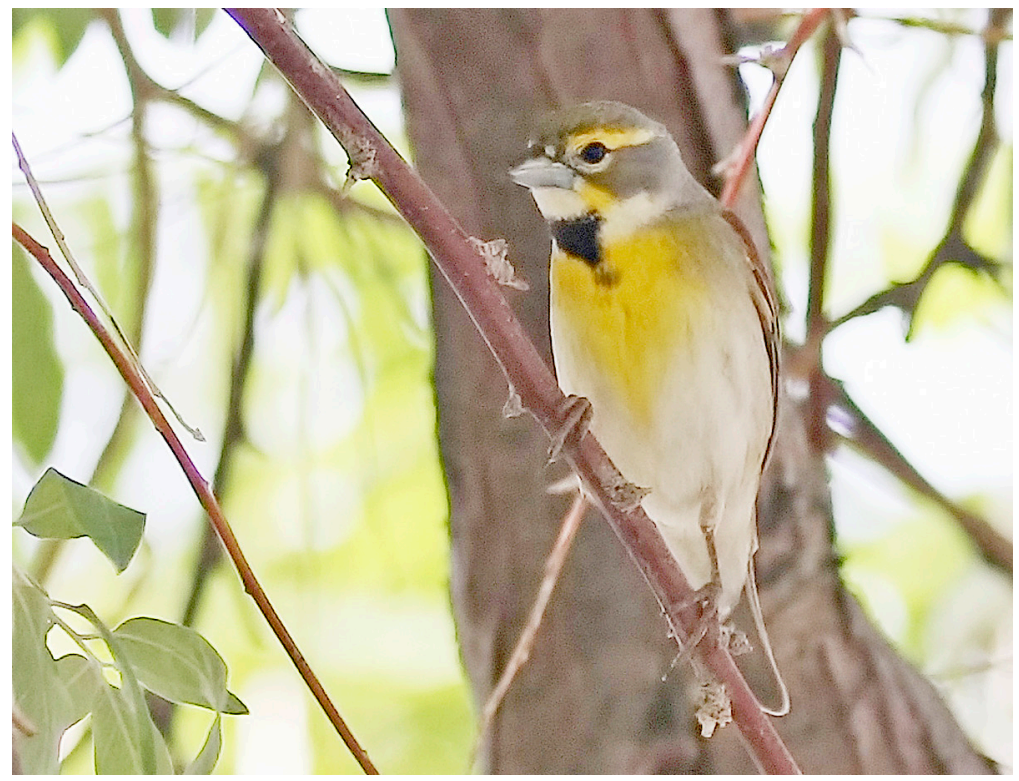

Figure 8. Dickcissel (Spiza americana), 5 Jun 2018, Miller's Rest Stop, Esmeralda County, Nevada. 
Arizona has two records of this species (Rosenberg et al. 2017), and California has 11 (McCaskie et al. 2018).

${ }^{*}$ GRASSHOPPER SPARROW Ammodramus savannarum (15**, 1). 2017-078, Sunset Park, Las Vegas (Clark), 26 Sep 2017. J. Streit (P).

*ORCHARD ORIOLE Icterus spurius $\left(14^{* *}, 1\right)$. 2018-032, Amargosa Valley (Nye), 26 Sep 1991. P. E. Lehman, S. Finnegan (P; AB 46:129, 1992). Earliest NBRC-endorsed record.

2017-060, Corn Creek, Desert NWR (Clark), 22-23 Sep 2017. NOT ENDORSED.

GOLDEN-WINGED WARBLER Vermivora chrysoptera $(6,1)$. 2018-036, Corn Creek, Desert NWR (Clark), 2 Jun 2018. J. Brady (P); J. Tinsman (P), G. Scyphers (P). Adult female.

CONNECTICUT WARBLER Oporornis agilis $(4,1)$. 2017-072, Miller's Rest Stop (Esmeralda), 15-17 Sep 1992. J. Brack (P; AB 47:126, 1993). Earliest NBRC-endorsed record. A hatch-year bird. This submission required three separate reviews by the committee; it passed when archived notes that accompanied the previously circulated photographs were found.

*KENTUCKY WARBLER Geothlypis formosa $\left(11^{\star *}, 3\right)$. 2018-016, Dyer (Esmeralda), 23 May 1981. P. E. Lehman; J. Langham (AB 35:848, 1981). Earliest NBRCendorsed record.

2018-018, Corn Creek, Desert NWR (Clark), 23 May 1987. K. Wallace (AB 41:470, 1987).

2018-019, Corn Creek, Desert NWR (Clark), 16 Jun 1992. M. Cressman (AB $46: 1159,1992)$.

HEPATIC TANAGER Piranga flava (3, 1). 2018-037, Cactus Springs (Clark), 4 Jun 2018. G. Scyphers (P; Figure 6), M. Meyers (P). Adult female. Although Austin and Bradley (1971) and Alcorn (1988) considered the species a rare summer visitor to the mountains of southern Nevada, the first Hepatic Tanager the NBRC endorsed (2002-18) was at a well-known vagrant/migrant trap, Miller's Rest Stop (Esmeralda), and this third one was also at a vagrant/migrant trap, a tiny oasis northwest of Indian Springs (Clark). The second (2014-043) was a male at Mt. Charleston (Clark) in the Spring Mountains, where breeding has been suspected but not confirmed. That male was accompanied by a yellow tanager not identified to species (Meyers 2016). The dearth of recent records from the Spring Mountains, noted also by Floyd et al. (2007), suggests that the Hepatic Tanager is not regular there, as Austin and Bradley (1971) and Alcorn (1988) implied.

${ }^{\star}$ SCARLET TANAGER Piranga olivacea $\left(9^{\star *}, 1\right) .2018-025$, Corn Creek, Desert NWR (Clark), 25 Oct 1987. NOT ENDORSED.

2017-071, Corn Creek, Desert NWR (Clark), 4-8 Nov 2017. N. McDonal (P; Figure 7); P. Gaffey (P), B. Zyla (P).

${ }^{\star}$ DICKCISSEL Spiza americana (12**, 1). 2018-034, Miller's Rest Stop (Esmeralda), 5 Jun 2018. K. Reed (P); M. Meyers (P; Figure 8). Adult male.

\section{ACKNOWLEDGMENTS}

The NBRC thanks everyone who contributed to the accounts contained in this report. All submissions, photos, advice, comments, and opinions are greatly appreciated. We apologize to anyone who may have been overlooked. Some of the contributors on this list are no longer with us, but their contributions are no less appreciated: Meg Andrews, Anthony Balatti, Jeff Bleam, John Brack, Joyce Brady, Judy Bundorf, Douglas Chang, Chuck Coxe, Donna Crail-Rugotzke, Marian Cressman, Dorothy Crowe, Desert NWR Corn Creek staff, Landon Dimitroff, Mark Dorries- 
field, Shawneen Finnegan, C. Gaffey, Patrick Gaffey, Dennis Ghiglieri, Jack Harman, Alexander Harper, Lauren Harter, Nancy Hoffman, Paul Hurtado, Scott Krammer, Jeri Langham, Paul Lehman, Tim Lenz, Richard McArthur, E. H. McClintock, Neil McDonal, Martin Meyers, Brandon Miller, Daniel Mitev, M. Vincent Mowbray, Colby Neumamn, Chris Nicolai, Fred Petersen, Angel Poe, Karla Joost Reed, Charles Ritter, Jim Roombos, Nick Rosen, Robert Rucker, Greg Scyphers, Justin Streit, Rose Strickland, Ellie Swanson, Jim Switalla, Jane Thompson, Jeanne Tinsman, Kevin Wallace, Fred Welden, Elizabeth Wells, Bobby Wilcox, Chad Wilhite, and Ben Zyla.

Outside review was provided by Daniel D. Gibson, Ryan S. Terrill, and Philip Unitt. Special thanks to Western Field Ornithologists and Great Basin Bird Observatory for their support and encouragement.

This annual report is dedicated to the memory of our good friend Neil McDonal.

\section{LITERATURE CITED}

Alcorn, J. R. 1988. The Birds of Nevada. Fairview West Publishing, Fallon, NV.

Austin, G. T., and Bradley, W. G. 1971. The avifauna of Clark County, Nevada. J. Ariz. Acad. Sci. 6:283-303; doi 10.2307/40022840.

Floyd, T., Elphick, C. S., Chisholm, G., Mack, K., Elston, R. G., Ammon, E. M., and Boone, J. D. 2007. Atlas of the Breeding Birds of Nevada. Univ. of Nev. Press, Reno.

McCaskie, G., Rottenborn, S. C., Terrill, S. B., and Benson, T. A. 2018. The $42^{\text {nd }}$ annual report of the California Bird Records Committee: 2016 records. W. Birds 49:238-257; doi 10.21199/WB49.4.1.

Meyers, M. 2015. Nevada Bird Records Committee report for 2013. W. Birds 46:8-27.

Meyers, M. 2016. Nevada Bird Records Committee report for 2014. W. Birds 47:120-137; doi 10.21199/WB47.2.2.

Rosenberg, G. H., Radamaker, K., and Vander Pluym, D. 2017. Arizona Bird Committee report, 2010-2014 records. W. Birds 48:74-112; doi 10.21199/WB48.2.1.

Singer, D. S., Benson, T. A., McCaskie, G., and Stahl, J. 2020. The $43^{\text {rd }}$ annual report of the California Bird Records Committee: 2017 records. W. Birds 51:2-20.

Tietz, J., and McCaskie, G. 2019. Update to Rare Birds of California, 1 January 2004-5 October 2019; www.californiabirds.org/cbrc_book/update.pdf.

Tinsman, J., and Meyers, M. 2018. Nevada Bird Records Committee report for 2016. W. Birds 49:98-112; doi 10.21199/WB49.2.1.

Tinsman, J., and Meyers, M. 2019. Nevada Bird Records Committee report for 2017. W. Birds 50:2-15; doi 10.21199/WB50.1.1.

Utah Bird Records Committee (UBRC). 2019. Documented sightings of Utah review species; www.utahbirds.org/RecCom/UBRC_SightingsIndex.html. 